FACTA UNIVERSITATIS

Series: Physical Education and Sport, Vol. 18, No 2, 2020, pp. 381 - 390

https://doi.org/10.22190/FUPES200614035D

Research article

\title{
THE INCIDENCE OF SPINAL POSTURAL DISORDERS IN FIRST-GRADE ELEMENTARY-SCHOOL STUDENTS
}

\author{
UDC 615.851.1
}

\author{
Stefan Đorđević, Bojan Jorgić, \\ Saša Milenković, Ratko Stanković, Mima Stanković
}

Faculty of Sport and Physical Education, University of Niš, Niš, Serbia

\begin{abstract}
The aim of this study is to determine the state of postural disorders in the sagittal and frontal planes of the spinal column, as well as any gender differences in first-year elementary school students. The participant sample comprised 138 school children, 73 male and 56 female participants, all from the territory of the municipality of Knjaževac, Serbia. The measuring instrument, the Formetric 4D System, Diers, Germany was used for the assessment of postural disorders of the spinal column. The testing results were presented in terms of frequencies and percentages, while the chisquare independence test was used to determine differences in spinal deformity incidence between male and female participants. The results obtained indicate that, in the sagittal plane, deformity was present in a total of $73.9 \%$ of the sample $(72.6 \%$ among the male and $75.4 \%$ among the female participants), whereas in the frontal plane this percentage amounted to $84.1 \%$ (84.9\% among the male, and $83.1 \%$ among the female ones). Moreover, the results indicate that no statistically significant differences were found in terms of the incidence of postural disorders between male and female participants in the sagittal plane $($ sig=0.859) and in the frontal plane of the spinal column (sig=0.949). In view of the results obtained, it can be concluded that a high incidence of spinal postural disorders in both the frontal and sagittal planes was equally present in participants of both genders.
\end{abstract}

Key words: Kyphosis, Lordosis, Scoliosis, Kypho-Lordosis, Flat Back, Gender Differences

Received June 14, 2020 / Accepted September 1, 2020

Corresponding author: Stefan Đorđević

Faculty of Sport and Physical Education, University of Niš, Čarnojevića 10a, Niš, Serbia

Phone: + $38118510900 •$ E-mail: stefan.robi.djordjevic@gmail.com

C 2020 by University of Niš, Serbia | Creative Commons License: CC BY-NC-ND 


\section{INTRODUCTION}

Postural status refers to the specific alignment of various segments of the human body which, under normal conditions, enables the most economical and rational movement, from the viewpoint of biomechanics and energy expenditure. In terms of deviations from normal postural status, there are irregularities located in parts of the locomotor apparatus (muscles, tendons, joints and bones) (Beganović \& Bošković, 2012), and, depending on their location in different regions of the locomotor apparatus, these can be functional or structural in character (Milenković, 2007). Irregularities, that is, deviations from normal postural status, present a growing problem in children (Jorgić \& Đorđević, 2016; Đorđević et al., 2016; Novaković, Đorđević, Aleksandrović, Pivač, \& Bjelica, 2016). Most frequently, postural disorders in children can be discerned on the frontal and sagittal planes of the spine (Živković, 2009).

Research results into the incidence of postural disorders on the sagittal plane indicate that, in children of a pre-school age, this percentage can go up to $40 \%$, while there are no statistically significant gender differences during this developmental stage (Romanov, Stupar, Međedović, \& Brkin, 2014). Furthermore, the incidence of spinal deformities on the sagittal plane in elementary-school children tends to be up to $40 \%$, with a significant difference between the thoracic and lumbar portions in terms of deformity incidence (Đorđević et al., 2016; Novaković et al., 2016), between 15 and 20\% for the thoracic segment, and up to $20 \%$ for the lumbar segment. Studies to date have also demonstrated the existence of gender differences in terms of the incidence of postural disorders on the sagittal plane (Đokić, Međedović, \& Smiljanić, 2011). In elementary-school children, deviations in the thoracic part of the sagittal plane are more frequently found among male subjects compared to female subjects, while the latter tend to exhibit a higher percentage of deviations in the lumbar portion of the spinal sagittal plane (Nikšić, Mahmutović, \& Rašidagić, 2015; Vukićević, Čokorilo, Lukić, Miličković, \& Bjelica, 2018).

The presence of postural disorders on the frontal plane of the spinal column has been found to be greater than 50\% (Protić-Gava, Šćepanović, \& Rakić, 2011; Stanojković, Vukmanović, Draganac, \& Petronić-Marković, 2012; Stančev, 2012). The results of studies conducted using elementary-school age participants indicate a significantly higher percentage of postural disorders on the frontal plane compared to the sagittal plane of the spine (Vukićević et al., 2018). Moreover, further analyses have discovered gender differences, in favor of female subjects, in the incidence of deviation from normal posture on the frontal plane of the spine (Đokić et al., 2011).

The diagnostic methods used in studies to date include: the Napoleon Wolanski method (Protić-Gava et al., 2011; Protić-Gava, Šćepović, \& Batez, 2013), the clinical method (Stanojković et al., 2012), inspection method (Petrović et al., 2012), somatometric and somatoscopic method (Đokić \& Stojanović, 2010; Đokić et al., 2011), the bending test and Cobb method (Đonović, Milić, Kocić, \& Radovanović, 2009), Spinal mouse (Jorgić et al., 2015a; Jorgić, Milenković, Milenković, Stanković, \& Bubanj, 2015b). The diagnostic methods employed to date were all non-invasive and allowed a high degree of subjectivity during assessment.

Based on the studies conducted so far into the incidence of spinal postural disorders on the frontal and sagittal planes in pre-school and elementary-school children, it is not possible to discern with clarity the incidence of deviation from normal posture on the frontal and sagittal planes of the spine, nor any attendant gender differences, particularly 
for first-year students. The seventh year of life, which coincides with elementary-school enrolment, is a crucial point during the juvenile period when development of postural disorders is concerned (Korovljev, Marinković, Roška, \& Madić, 2015).

In accordance with the above mentioned, the aim of this study is to determine the state of postural disorders in the sagittal and frontal planes of the spinal column, as well as any gender differences in first-year elementary school students.

\section{METHODS}

\section{The sample of participants}

The sample of participants comprised first-year students of the elementary schools "Dimitrije Todorović Kaplar," "Vuk Karadžić" and "Mladost," all in the municipality of Knjaževac, Serbia. The total number of participants included in the study was 138 (height 127.93 \pm 6.06 ; mass 27.09 \pm 6.42 and Body Mass Index-BMI 16.64 \pm 3.21 ), where 73 participants were male (height $127.96 \pm 5.83$; mass $27.49 \pm 6.48$ and BMI 16.49 \pm 2.95 ) and 65 participants were female (height 127.91 \pm 6.34 ; mass $27.94 \pm 6.56$ and BMI 16.80 \pm 3.49 ).

The participants were tested during the months of April and May during the 2018/2019 academic school year. Consent for participation in the study was obtained from school principals and first-grade teachers at the above mentioned elementary schools, in the form of a confirmation of participation in the Interreg IPA project: "Development of diagnostic centers for postural and muscular-skeletal disorders in schoolchildren in Serbia and Bulgaria".

\section{Measures}

The standardized anthropometric instrument (SECA model 284; SECA, Hamburg, Germany) was used in order to determine the descriptive parameters of the tested sample: body height, mass, BMI. This instrument is a cutting-edge anthropometric station, compliant with the most stringent criteria as determined by the International Society for the Advancement of Kinanthropometry-ISAK (Stewart, Marfell-Jones, \& Olds, 2011). The measuring device (Formetric 4D System, Diers, Germany) was used for determining the postural status of the sagittal and frontal planes of the spine. Methodology in the diagnostics of postural status in children and adults is non-invasive (Betsch et al., 2011; Mangone, Raimondi \& Paoloni, 2013; Đorđević, Vidojević, Đokić, Milenković, \& Stanković, 2018). Diagnostics is performed using photometry, which in turn is based on the principle of triangulation. The reliability and validity of the instrument was established in earlier studies (Somoskeöy, Tunyogi-Csapó, Bogyó, \& Illés, 2012; Lason, Peeters, Vandenberghe, Byttebier, \& Comhaire, 2015). The device relies on the Cobb method to calculate the angle of the physiological curves of the spinal column in the frontal and sagittal planes.

In accordance with the reference values for normal posture, as well as for deviation from normal posture for the sagittal plane (Schröder, Stiller, \& Mattes, 2011), the following variables were used: normal posture on the sagittal plane, kyphotic bad posture, flat back in the thoracic portion of the sagittal plane of the spine, lordotic bad posture, flat back in the lumbar portion of the sagittal plane of the spine, kypho-lordotic bad posture, flat back in the thoracic and lumbar segments of the sagittal plane, flat back in the 
thoracic portion and lordotic bad posture in the lumbar portion of the spine, kyphotic bad posture and flat back in the lumbar portion.

The variables used for assessing the status of the spinal column on the frontal plane included: Normal spinal posture on the frontal plane, left thoracic scoliotic bad posture I degree, left thoracic scoliotic bad posture II degree, right thoracic scoliotic bad posture I degree, right thoracic scoliotic bad posture II degree, left lumbar scoliotic bad posture I degree, left lumbar scoliotic bad posture II degree, right lumbar scoliotic bad posture I degree, right lumbar scoliotic bad posture II degree, total left scoliotic bad posture I degree, total left scoliotic bad posture II degree, total right scoliotic bad posture I degree, total right scoliotic bad posture II degree, duplex scoliotic left thoracic and right lumbar posture I degree, duplex scoliotic left thoracic and right lumbar posture II degree, scoliosis duplex right thoracic and left lumbar posture I degree, scoliosis duplex right thoracic and left lumbar posture II degree. The rankings for determining variables were adopted from the study by Devedžić and associates (2016).

\section{Statistical data analysis}

Testing results were presented as means and standard deviation, as well as in the form of frequencies and percentages. The Chi-Squared Independence Test was used to determine any differences in the incidence of spinal deformity on the sagittal and frontal planes between male and female participants. Statistical analysis of the obtained results was conducted using the software SPSS version 20.

\section{RESULTS}

Table 1 Postural status in the sagittal plane

\begin{tabular}{lccc}
\hline & \multicolumn{3}{c}{ Participants } \\
\cline { 2 - 4 } & $\begin{array}{c}\text { Male and female } \\
(№ / \%)\end{array}$ & $\begin{array}{c}\text { Male } \\
(\text { №/\% })\end{array}$ & $\begin{array}{c}\text { Female } \\
\text { (№/\% })\end{array}$ \\
\hline Normal posture & $36 / 26.1$ & $20 / 27.4$ & $16 / 24.6$ \\
Kyphotic bad posture & $8 / 5.8$ & $4 / 5.5$ & $4 / 6.2$ \\
Flat back in the thoracic segment of the sagittal plane & $31 / 22.5$ & $18 / 24.7$ & $13 / 20.0$ \\
Lordotic bad posture & $16 / 11.6$ & $4 / 5.5$ & $12 / 18.5$ \\
Flat back in the lumbar segment of the sagittal plane & $13 / 9.4$ & $8 / 11.0$ & $5 / 7.7$ \\
Kypho-lordotic bad posture & $6 / 4.3$ & $2 / 2.7$ & $4 / 6.2$ \\
Flat back in thoracic and lumbar segments of the sagittal plane & $25 / 18.1$ & $16 / 21.9$ & $9 / 13.8$ \\
Thoracic flat back and lordotic bad posture & $3 / 2.2$ & $1 / 1.4$ & $2 / 3.1$ \\
Number of participants & 138 & 73 & 65 \\
\hline
\end{tabular}

Table 1 provides the basic descriptive statistics parameters on the incidence, presented in the form of numbers and percentages, of the spinal deformity on the sagittal plane in first-year elementary-school children from the municipality of Knjaževac. The data obtained regarding normal posture on the sagittal plane, for the total sample, are given as follows: normal posture was found in 36 participants, i.e., 26.1\%, whereas deviations were found in 102 participants (73.9\%). The data indicate a rather small deviation in terms of the percentages of normal posture for boys $(27.4 \%)$ and girls $(24.6 \%)$. In addition, a much greater incidence of abnormality of the physiological curve in the lumbar segment was found compared to the 
thoracic segment: kyphotic bad posture accounted for 5.8\% of the total sample, with $5.5 \%$ among the boys and $6.2 \%$ among the girls, whereas lordotic bad posture was present in $11.6 \%$ of the total sample, namely $5.5 \%$ among the male participants and $18.5 \%$ among the female participants. The disorder with the greatest incidence was an insufficiently developed physiological curve, found in $52.2 \%$ of the total sample, $59 \%$ among the male and $44.6 \%$ among the female participants.

Table 2 Postural status in the sagittal plane

\begin{tabular}{|c|c|c|c|}
\hline & \multicolumn{3}{|c|}{ Participants } \\
\hline & $\begin{array}{c}\text { Male and } \\
\text { female } \\
(№ / \%)\end{array}$ & $\begin{array}{l}\text { Male and } \\
\text { female } \\
(№ / \%)\end{array}$ & $\begin{array}{c}\text { Male and } \\
\text { female } \\
(№ / \%)\end{array}$ \\
\hline Normal spinal posture & $22 / 15.9$ & $11 / 15.1$ & $11 / 16.9$ \\
\hline Left thoracic scoliotic bad posture of the I degree & $24 / 17.4$ & $15 / 20.5$ & $9 / 13.8$ \\
\hline Left thoracic scoliotic bad posture of the II degree & $2 / 1.4$ & $2 / 2.7$ & \\
\hline Right thoracic scoliotic bad posture I degree & $24 / 17.4$ & $15 / 20.5$ & $9 / 13.8$ \\
\hline Right thoracic scoliotic bad posture of the II degree & $2 / 1.4$ & $1 / 1.4$ & $1 / 1.5$ \\
\hline Left lumbar scoliotic bad posture I degree & $5 / 3.6$ & $3 / 4.1$ & $2 / 3.1$ \\
\hline Right lumbar scoliotic bad posture I degree & $4 / 2.9$ & $1 / 1.4$ & $3 / 4.6$ \\
\hline Total left scoliotic bad posture I degree & $15 / 10.9$ & $8 / 11.0$ & $7 / 10.8$ \\
\hline Total left scoliotic bad posture II degree & $3 / 2.2$ & $2 / 2.7$ & $1 / 1.5$ \\
\hline Total right scoliotic bad posture I degree & $7 / 5.1$ & $1 / 1.4$ & $6 / 9.2$ \\
\hline Total right scoliotic bad posture II degree & $4 / 2.9$ & $1 / 1.4$ & $3 / 4.6$ \\
\hline Duplex scoliotic left thoracic and right lumbar posture I degree & $8 / 5.8$ & $4 / 5.5$ & $4 / 6.2$ \\
\hline Duplex scoliotic left thoracic and right lumbar posture II degree & $2 / 1.4$ & $1 / 1.4$ & $1 / 1.5$ \\
\hline Duplex scoliotic right thoracic and left lumbar posture of the I degree & $14 / 10.1$ & $8 / 11.0$ & $6 / 9.2$ \\
\hline Duplex scoliotic right thoracic and left lumbar posture of the II degree & $2 / 1.4$ & & $2 / 3.1$ \\
\hline Number of participants & 138 & 73 & 65 \\
\hline
\end{tabular}

Table 2 presents results which refer to the frontal plane, with results presented in the form of numbers and percentages, as well. The data obtained regarding normal posture in the frontal plane, for the total sample, are given as follows: normal posture was found in 22 participants, or $15.9 \%$ of the total sample, while some form of deviation was found in 116 participants, or $84.1 \%$ of the total sample. The data indicate very small deviations between boys and girls regarding the percentage for normal posture, $15.1 \%$ and $16.9 \%$, respectively. In addition, there is significantly greater incidence of abnormality of the physiological curve in the left and right thoracic portion, compared to: the right and left sides of the lumbar portion: scoliotic left thoracic bad posture $(18.8 \%)$ and right thoracic bad posture (18.8\%); left lumbar deviation (3.6\%) and right lumbar deviation $(2.9 \%)$, in the thoracic portion of the spinal column in male participants: left $(23.2 \%)$, right $(21.9 \%)$, and in the lumbar portion: left $(4.1 \%)$ and right $(1.4 \%)$; among the female participants: thoracic left $(13.8 \%)$ and right $(15.3 \%)$, and lumbar left $(3.1 \%)$ and right $(4.6 \%)$. The results also indicate a significantly greater number of deviations on the frontal plane which are of a functional first degree (73.2\%), compared to the second degree $(10.7 \%)$; in the boys, this percentage for the first degree of deformity was $(75.4 \%)$, and $(9.6 \%)$ for the second degree of deformity, whereas for the girls the percentage for the first degree of deformity was $(70.7 \%)$ and $(12.2 \%)$ for the second degree of deformity. 
Table 3 Difference between the male and female participants in terms of the postural status

\begin{tabular}{lcccc}
\hline \multicolumn{5}{c}{ Difference between male and female participants in terms of postural status on the sagittal plane } \\
\hline & Value & df & P & phi coefficient / degree of effect \\
\cline { 2 - 5 } Continuity Correction & .031 & 1 & .859 & .032 (medium) \\
N of Valid Cases & 138 & & & \\
\hline Difference between male and female participants in terms of postural status on the frontal plane \\
\hline Continuity Correction \\
N of Valid Cases & .004 & 1 & .949 & -.025 (low) \\
\hline
\end{tabular}

Table 3 presents the results obtained based on Yates' Correction for Continuity, which compensates for the overestimation of the value of the chi-squared test which is a consequence of the low number of dimensions. The tables indicate that there is no statistically significant difference ( $\mathrm{sig}=0.859$ ) between male and female participants in the study in terms of the incidence of postural disorders on the sagittal plane, expressed as a percentage. Additionally, no statistically significant difference ( $\operatorname{sig}=0.949)$ was found between the genders regarding disorders on the frontal plane of the spine.

\section{DISCUSSION}

The results of this study indicate a deviation from normal posture on the sagittal and frontal planes in a high percentage. Deviation from normal posture on the sagittal plane, that is, postural disorders, were found in the thoracic and lumbar portion in a total of $73.9 \%$, namely in $72.6 \%$ of the male participants and in $75.4 \%$ of the female participants. Earlier studies looking into a similarly aged, also juvenile, sample of participants, have reported high percentages of postural disorders of a functional type (Milenković, 2007; Dragić, Midić, \& Midić, 2012; Protić-Gava et al., 2013; Jorgić et al., 2015b; Vukićević et al., 2018). More detailed analysis yields that, from the total percentage of postural disorders on the sagittal plane, the greatest percentage is accounted for by a lack of a physiological curve $(50 \%)$ in the thoracic $(22.5 \%)$, lumbar segments $(9.4 \%)$ and thoracolumbar segments of the spine $(18.1 \%)$, with very little difference between the genders (among the male participants in the thoracic $(24.7 \%)$, lumbar $(11 \%)$ and thoracolumbar segments $(21.9 \%)$; among the female participants, it is in the thoracic (20\%), lumbar $(7.7 \%)$ and thoracolumbar portion of the spine (13.8\%)). Furthermore, Table 1 indicates the percentage of postural disorders on the sagittal plane which accounts for an over-pronounced physiological curve in the thoracic portion and lumbar portion of the spine $(23.9 \%)$. While the percentage of an over-pronounced physiological curve on the sagittal plane in relation to the gender of the participants is the following: for the male participants it is $(5.5 \%)$ in the thoracic segment, $(6.9 \%)$ in the lumbar and thoracolumbar segments $(2.7 \%)$; and for the females it is $(6.2 \%)$ in the thoracic segment and $(21.6 \%)$ in the lumbar segment and thoracolumbar segments of the spine $(6.2 \%)$. The results obtained in the present study are very similar to those obtained in earlier studies (Dragić et al., 2012; Protić-Gava et al., 2013; Vukićević et al., 2018).

Postural disorders located on the frontal plane indicate a high incidence percentage, with $84.9 \%$ among the male participants and $83.1 \%$ among the female participants, which is in accordance with the findings of earlier studies looking into the same age group (Vukićević et al., 2018). A more detailed analysis of the results obtained clearly indicates that a functional first degree constitutes the highest percentage, among the male participants 
75.4\% and among the female participants $70.7 \%$, where changes have occurred strictly due to muscular imbalance (Živković, 2009; Jovović \& Čanjak, 2011), whereas a functional second degree is found at a percentage of $(10.9 \%)$, with (9.5\%) among the male participants and $(12.4 \%)$ among the female participants. Furthermore, an analysis of the results clearly indicates a higher concentration of partial disorders on the frontal plane (44.1\%), primarily in the thoracic region (37.6\%), compared to the lumbar region $(6,5 \%)$, while total and duplex scoliotic bad posture is found in the percentage (39.8\%). Earlier studies also indicate an approximately equal incidence, in terms of percentages, of postural disorders on the frontal plane in the same age group (Vukićević et al., 2018). Some of the causes of the emergence of such functional disorders on the frontal plane of the spine might lie in muscle imbalance due to long periods spent in an incorrect seated posture, carrying heavy schoolbags, a sedentary lifestyle, and ever-increasing hypokinesia encountered in this age group (Stanojčić et al., 2019).

An analysis of results regarding the incidence of postural disorders of the spinal column did not yield statistically significant differences between the male and female participants on the sagittal plane $(\operatorname{sig}=0.859)$, or on the frontal plane $(\operatorname{sig}=0.949)$; similarly, earlier studies (Protić-Gava, Krsmanović, Jevtić, Kadović, \& Romanov, 2009; Protić-Gava, Krneta, Bošković, \& Romanov, 2010; Protić-Gava et al., 2013; Vukićević et al., 2018) also found no differences in this developmental period, whereas at the start of adolescence there is a statistically significant difference. Results thus obtained may indicate that there are no gender differences in this respect, for this particular developmental period, as a result of similar habits and behaviors, as well as due to effects of the omnipresence of a contemporary sedentary lifestyle (Stanojčić et al., 2019). Also, this developmental period tends to be characterized by biological maturity following chronological age, which is not the case during the onset of adolescence, where we find statistically significant gender differences in terms of the incidence of postural disorders of the spine.

\section{CONCLUSION}

Based on the results obtained in the present study, there is an exceptionally high incidence of postural disorders of the spinal column. Also, in terms of the presence of deformities at this particular age of development, no difference between the genders was found, on the sagittal or on the frontal plane of the spine. It can be concluded that the first grade of elementary school is an important period for preventive action to be taken by professionals in the field of kinesitherapy and corrective gymnastics, both in the form of educating the parents, teachers and children, and in the form of specific measures, i.e., specific exercises aimed at prevention and correction, within the framework of physical education classes that are a part of the first-grade elementary school curriculum. Finally, preventive and corrective gymnastics programs can also form part of activities which can be provided by physical education teachers and physical therapists within the framework of fitness centers. 
Acknowledgment: The authors wish to thank the Sports Association of Knjaževac for their collaboration and for allowing us to use their diagnostic center for the assessment of spinal postural status in first-grade elementary school children from the municipality of Knjaževac, using the device Formetric 4D System, Diers, Germany, as part of the Interreg IPA project "Development of diagnostic centres for postural and musculo-skeletal disorders in school children in Serbia and Bulgaria," no. CB007.1.21.129. We also owe a special debt of gratitude to the Ministry of Education, Science and Technological Development of the Republic of Serbia, for their support and for making this study possible, as part of the project no. OI179024.

\section{REFERENCES}

Betsch, M., Wild, M., Jungbluth, P., Hakimi, M., Windolf, J., Haex, B., et al. (2011). Reliability and validity of 4D rasterstereography under dynamic conditions. Computers in Biology and Medicine, 41(6), 308-312.

Beganović, E., \& Bešović, M. (2012). Analiza držanja tela kod učenika mlađeg školskog uzrasta na području grada Sarajeva (Analysis of body posture in young school-age students in Sarajevo city area). Sportski logos, 10(19), 25-33.

Devedžić, G., Ćuković, S., Luković, V., Luković, T., Milošević, D., Jovanović, Z., et al. (2016). Bioinženjering skolioze (Bioengineering of scoliosis). Kragujevac: Faculty of Engineering University of Kragujevac. In Serbian

Dragić, B., Midić, D., \& Midić, M. (2012). Posturalni poremećaji na kiĉmenom stubu u sagitalnoj ravni kod školske dece (Postural disorders of the spinal cord in the sagittal plane in schoolchildren). Godišnjak Učiteljskog fakulteta u Vršcu, 3, 279-290. In Serbian

Đokić, Z., \& Stojanović, M. (2010). Morfološke karakteristike i posturalni status dece od 9 do 12 godina na području Sremske Mitrovice. Opšta Medicina (Morphologic characteristics and postural status in children aged 9 to 12 years in Sremska Mitrovica municipality), 16(1-2), 41-49. In Serbian

Đokić, Z., Međedović, B., \& Smiljanić, J. (2011). Stanje uhranjenosti, posturalni status i kvalitet sprovođenja nastave fizičkog vaspitanja u osnovnim školama (Nutritional status, postural status and quality of teaching of physical education in elementary schools). TIMS Acta, 5(1), 10-19. In Serbian

Đonović, N., Milić, Č., Kccić, S., \& Radovanović, S. (2009). Skolioza kod maldih od 7-18 godina i uslovi rada u osnovnim i srednjim školama na teritoriji grada Kragujevca (Scoliosis in young people aged 7-18 and working conditions in primary and secondary schools in the city of Kragujevac). Medicinski Pregled/ Medical Review, 62(9-10), 445-449. In Serbian

Đorđević, S., Jorgić, B., Milenković, S., Milenković, M., Đokić, M., \& Tsonkova, D. (2016). Representation of kyphosis deformities in children of primary school in the Republic of Serbia: a systematic rewiew study. In: V. Živković (Ed.). $2^{\text {nd }}$ International Scientific Conference „, Research in Physical Education, Sport and Health “, (pp. 227-333). Skoplje: Faculty of Physical Education, Sport and Health.

Đorđević, S., Vidojević, M., Đokić, M., Milenković, M., \& Stanković, R. (2018). The postural status of female first league basketball players. In: M. Kocić (Ed). 21 Scientific Conference „FIS Communications 2018" in Physical Education, Sport and Recreation, (pp. 299-303). Niš: Faculty of Sport and Physical Education, University of Niš.

Jorgić, B., Milenkovič, M., Ždrele, S., Milenković, S., Stanković, R., \& Bubanj, S. (2015a). Spinal cord posture in the sagittal plane among young schoolchildren residing in the area of Knjaževac. Facta Universitatis Series Physical Education and Sport, 13(2), 311-318.

Jorgić, B., Milenković, M., Milenković, S., Stanković, R., \& Bubanj, S. (2015b). The frequency of scoliotic body posture among young children in Knjaževac. In: S. Pantelić (Ed). 18 Scientific Conference „FIS Communications 2015" in Physical Education, Sport and Recreation, (pp. 166-170). Niš: Faculty of Sport and Physical Education, University of Niš.

Jorgić, B., \& Đorđević, S. (2016). Učestalost deformiteta skolioze kod dece predškolskog uzrasta u Republici Srbiji: sistematsko pregledno istraživanje (The incidence of scoliosis deformities in preschool children in the Republic of Serbia: a systematic review study). In M. Đuričković (Ed.). Book of abstracts of the first International Conference „An educator in the 21st century“, (p. 37). High School for Educators of Vocational Studies in Aleksinac. In Serbian

Jovović, V., \& Čanjak, R. (2011). Oscilacije devijacija kičmenog stuba kod školske djece zavisno od uzrasnog doba (Oscillations of the spinal deviations of the school children depending on the ages). Glasnik Antropološkog društva Srbije, 46, 369-376.

Korovljev, D., Marinković, D., Roška, M., \& Madić, D. (2015). Posturalni status kičmenog stuba kod dečaka uzrasta od 4-13 godina. In: Z. Grgantov, S. Krstulović, J. Paušić, T. Bavčević, D. Čular, A. Kezić, \& A. 
Miletić (Eds). 5th International Scientific Conference „Contemporary Kinesiology“, (pp. 425-434). Split: Faculty of Kinesiology, University of Split. In Croatian

Lason, G., Peeters, L., Vandenberghe, K., Byttebier, G., \& Comhaire, F. (2015). Reassessing the accuracy and reproducibility of Diers formetric measurements in healthy volunteers. International Journal of Osteopathic Medicine, 18(4), 247-254.

Mangone, M., Raimondi, P., \& Paoloni, M. (2013). Vertebral rotation in adolescent idiopathic scoliosis calculated by radiograph and back surface analysis-based methods: correlation between the Raimondi method and rasterstereography. European Journal for Spine, 22, 367-371.

Milenković, S. (2007). Korektivna gimnastika, teorija $i$ vežbe (Corrective gymnastics, theory and exercises). Niš: Autonomous edition of the author. In Serbian

Nikšić, E., Mahmutović, I., \& Rašidagić, F. (2015). Postularni poremećaji kičmenog stuba kod učenika razredne nastave $\mathrm{u}$ odnosu na pol (Postular disorders of the spinal column in primary school students in relation to gender). In: M. Jovanović, \& Đ. Nićin (Eds.). Fifth International Conference on "Sport Science and Health", (pp. 100-112). Pan-European University "APEIRON": Banja Luka. In Serbian

Novaković, V., Đorđević, S., Aleksandrović, M., Pivač, N., \& Bjelica, B. (2016). The incidence of lordotic deformity in children under the age of 15 in the Republic of Serbia: a systematic review. In: S. Pamtelic (Ed). 19 Scientific Conference ,FIS Communications 2016" in Physical Education, Sport and Recreation, (pp. 291-294). Niš: Faculty of Sport and Physical Education, University of Niš.

Petrović, J., Puzović, V., Đorđević, D., Obrenović, M., Medić, V., \& Jakovljević, V. (2012). Prevalence of spine deformity among 7-11 year old children. Medicinski Časopis, 46(4), 187-190.

Protić-Gava, B., Krsmanović, T., Jevtić, N., Kadović, V, \& Romanov, R. (2009). Postural disorders in sagital plane and deferences according to gender. Fizička kultura, 37 (2), 134-137.

Protić-Gava, B., Krneta, Ž., Bošković, K., \& Romanov, R. (2010). Efekti programiranog vežbanja na status kičmenog stuba osmogodišnje dece Novog Sada (The effects of programmed exercises on the spinal column posture in the eight-year-olds in Novi Sad). Glasnik Antropološkog Društva Srbije, 45, 365-374.

Protić-Gava, B., Šćepanović, T., \& Rakić, D. (2011). Razlike u posturalnim poremećajima kičmenog stubafrontalne ravni adolescenata grupisanih prema morfološkim karakteristikama. Glasnik Antropološkog Društva Srbije, 46(5), 407-414

Protić-Gava, B., Śćepović, T., \& Batez, M. (2013). Body posture in young schoolchildren in a Novi Sad elementary school. Resaarch in Kinesiology, 41(2), 146-149.

Romanov, R., Stupar, D., Međedović, B., \& Brkin, D. (2014). Postural status of preschool children in Novi Sad. TIMS Acta, 8(2), 129-135.

Schröder, J., Stiller, T., \& Mattes, K. (2011). Referenzdaten in der Wirbelsäulenformanalyse (Reference data in the whirlpool form analysis). Manuelle Medizin, 49(3), 161-166. In German

Somoskeöy, S., Tunyogi-Csapó, M., Bogyó, C., \& Illés, T. (2012). Clinical validation of coronal and sagittal spinal curve measurements based on three-dimensional vertebra vector parameters. The Spine Journal, 12(10), 960-968.

Stewart, A., Marfell-Jones, M., \& Olds, T. (2011). HR International standards for anthropometric assessment. Australia: International Society for the Advancement of Kinanthropometry.

Stanojković, B., Vukmanović, M., Draganac, S., \& Petronić-Marković, I. (2012). Učestalost pridruženih deformiteta kičme kod školske dece sa ravnim stopalima (The incidence of associated spinal deformities in school children with flat feet). In: M. Lazović (Ed.), 12 međunarodni kongres fizijatara Srbije „Metodološki pristupi-rezultati i dileme u rehabilitaciji“" (12th International Congress of Physiatrists of Serbia "Methodological approaches-results and dilemmas in rehabilitation"), (pp. 87-88). May, 17-20, 2012, Belgrade: Association of Physiatrists of Serbia. In Serbian

Stanojčić, A., Vukićević, V., Čokorilo, D., Lukić, N., Pajić, N., Miličković, V., et al. (2019). Korelati životnih navika i posturalnog statusa dece mlađeg školskog uzrasta (Correlations between life habits and postural status of young school children.). Glasnik Antropološkog društva Srbije, 54, 49-61. In Serbian

Stančev, L. (2012). Deformiteti kičmenog stuba kod učenika od V do VIII razreda osnovne škole „Dušan Radović "Bor (Spinal deformities in students from 5th to 8th grade of elementary school "Dušan Radović" Bor). Bor: Centar za talente Bor. In Serbian

Vukićević, V., Čokorilo, D., Lukić, N., Miličković, V., \& Bjelica, M. (2018). The presence of postural disorders in children of the younger school age. Timočki Medicinski Glasnik, 43(3), 100-107.

Živković, D. (2009). Osnove kineziologije sa elementima kliničke kineziologije (Fundamentals of kinesiology with elements of clinical kinesiology). Niš: Faculty of Sport and Physical Education, University of Niš. In Serbian 


\section{UČESTALOST POSTURALNIH POREMEĆAJA KIČMENOG STUBA UČENIKA PRVOG RAZREDA OSNOVNE ŠKOLE}

Cilj istraživanja bio je da se utvrdi zastupljenost i razlika prema polu u posturalnim poremećajima kičmenog stuba u sagitalnoj i frontalnoj ravni učenika prvog razreda osnovne škole. Uzorak ispitanika sačinjavalo je 138 učenika, tj., 73 ispitanika muškog pola $i$ 65ispitanika ženskog poila sa teritorije gradske opštine Knjaževac, Srbija. U proceni posturalnih poremećaja kičmenog stuba korišćen je merni instrument Formetric 4D System, Diers, Germany. Rezultati merenja predstavljeni frekvenciono $i$ procentualno, dok je za utvrđivanje razlika u zastupljenosti deformiteta kičmenog stuba između ispitanika muškog $i$ ženskog pola korišćen je Hi kvadrat test za testiranje nezavisnosti. Rezultati su ukazali da je u sagitalnoj ravni prisutnost deformiteta na ukumnom uzorku $73.9 \%$ (kod ispitanika muškog pola $72.6 \%$ i kod ispitanika ženskog pola $75.4 \%$ ), dok je u frontalnoj ravni taj procenat generalno iznosio $84.1 \%$ (kod ispitanika muškog pola $84.9 \%$ i kod ispitanika ženskog pola $83.1 \%$ ). Takođe, rezultati su ukazali da nisu uočene statistički značajne razlike u zastupljhenosti posturalnih poremećaja između ispitanika muškog $i$ ženskog pola u sagitalnoj (sig=0.859) $i$ frontalnoj ravni kičmenog stuba (sig=0.949). U skladu sa dobijenim rezultatima može se zaključiti da je visok nivo zastupljenosti postualnih poremećaja kičmenog stuba u frontalnoj i sagitalnoj ravni podjednako prisutan kod ispitanika oba pola.

Ključne reči: kifoza, lordoza, skolioza, kifolordoza, ravna leđa, polne razlike 